\title{
Pengaruh Suplementasi Vitamin A Terhadap Campak
}

\author{
Zakiudin Munasir
}

Peran vitamin A dan imunitas sudah banyak dibuktikan dari penelitian sebelumnya. Peran suplementasi vitamin A pada imunisasi campak telah diteliti pada bayi usia 6 bulan di daerah Bogor yang merupakan daerah endemi defisiensi vitamin A. Penelitian dilakukan secara acak buta ganda, uji klinis kontrol plasebo terhadap 336 bayi usia 6 bulan. Subjek dibagi 2 kelompok yaitu kelompok yang mendapat suplementasi vitamin A dosis tinggi (100.000 IU) dan kelompok yang mendapat plasebo pada saat imunisasi campak. Hasil serokonversi terhadap antibodi campak setelah 1 bulan imunisasi adalah $78,5 \%$ pada kelompok vitamin A dan $84,7 \%$ pada kelompok plasebo $(\mathrm{p}=0,16)$ sedangkan 6 bulan setelah imunisasi didapatkan hasil serokonversi 74,6\% pada kelompok vitamin A dan $81,8 \%$ pada kelompok plasebo $(p=0,13)$. Perbedaan yang bermakna terlihat pada kelompok bayi yang masih mempunyai titer antibodi maternal terhadap campak yang masih tinggi (>1:25) yaitu serokonversi 1 bulan setelah imunisasi sebesar $43,7 \%$ pada kelompok vitamin A dan 64,4\% pada kelompok plasebo ( $\mathrm{p}=0,04)$ serta titer protektif setelah 6 bulan sebesar 50,0\% pada kelompok vitamin A dan 69,6\% pada kelompok plasebo $(p=0,03)$. Dijumpai pula bayi yang mendapat vitamin $A$, jumlah ruam setelah imunisasi lebih sedikit daripada kelompok yang tidak mendapat vitamin A. Sebagai kesimpulan dapat dikemukakan bahwa vitamin A dapat menghambat replikasi virus vaksin campak.

enyakit campak masih merupakan masalah kesehatan di banyak negara di dunia terutama di negara sedang berkembang seperti Indonesia. Penyakit ini mudah dikenali karena gejala klinisnya yang khas dan merupakan penyakit universal. Gejala bervariasi dari yang ringan sampai yang fatal. Pada anak yang belum mempunyai kekebalan terhadap campak hampir semua pernah menderita campak pada usia dini. ${ }^{1}$ Diperkirakan sekitar 6-7 juta anak menderita campak dengan kematian sekitar 2 juta tiap tahun. ${ }^{2}$ Sebetulnya penyakit campak sudah dikenal sejak zaman nenek moyang kita dan mereka menganggap bahwa campak adalah suatu hal yang seharusnya terjadi sehingga tidak perlu diobati. Bahkan sampai sekarang ada anggapan bahwa ruam

Alamat korespondensi:

Dr. Zakiudin Munasir Sp.A(K)

Subbagian Alergi \& Imunologi, Bagian Ilmu Kesehatan Anak FKUIRSCM, Jl. Salemba 6, Jakarta 10430.

Telpon: (021) 3161144, Fax.: (021) 3913982. campak harus keluar karena kalau tidak keluar dapat menyebabkan kematian. Oleh karena itu banyak usaha dilakukan untuk mempercepat keluarnya ruam ini diantaranya dengan merendam anak di sungai yang justru dapat menimbulkan komplikasi yang berat.

Defisiensi vitamin A merupakan penyebab utama kesakitan dan kematian di negara berkembang. ${ }^{3}$ Berbagai penelitian membuktikan bahwa vitamin A mempunyai efek terhadap peningkatan fungsi imunitas selular dan humoral. Oleh karena itu manfaat suplementasi vitamin A pada pasien campak sudah banyak diteliti dan dibuktikan.

Vitamin A merupakan mikronutrien penting yang diperlukan untuk fungsi kekebalan tubuh spesifik maupun non spesifik. Defisiensi vitamin A dilaporkan dapat menyebabkan gangguan kekebalan humoral ${ }^{4}$ serta selular. ${ }^{5}$ Efek antioksidan dari karotenoid ini secara tidak langsung dapat meningkatkan fungsi kekebalan tubuh dengan jalan menurunkan konsentrasi partikel bebas beserta produknya yang bersifat imunosupresif. Mencegah oksidasi leukosit sehingga dapat menurunkan 
kadar prostaglandin yang bersifat imunosupresif. ${ }^{6}$ Peningkatan masukan diet antioksidan dibuktikan dapat menurunkan konsentrasi peroksidase lipid, konsentrasi prostaglandin yang diproduksi oleh makrofag yang selanjutnya meningkatkan respons hipersensitivitas tipe lambat dan proliferasi limfosit. ${ }^{7}$ Vitamin A dapat juga bersifat sebagai ajuvan dengan jalan merusak membran lisosom yang dapat merangsang pembelahan sel pada vitamin A saat antigen berada dalam sel. ${ }^{8}$ Definisi ajuvan di sini menurut Freud ${ }^{9}$ adalah suatu zat yang dapat meningkatkan respons imun terhadap suatu imunogen. Lisosom ini dapat mempunyai peran dalam memulai terjadinya pembelahan sel. Kerusakan lisosom ini akan merangsang sistim imun. Vitamin A berperan pula dalam proses epitelisasi. Dengan peningkatan proses ini maka akan terjadi perbaikan fungsi pertahanan fisik non spesifik terhadap antigen yang masuk ke dalam tubuh.

Untuk mengetahui efek suplementasi vitamin A dosis tinggi pada imunisasi campak telah dilakukan penelitian secara acak, buta ganda, uji klinis kontrol plasebo terhadap bayi usia 6 bulan yang diambil dari 12 desa di daerah Bogor, Jawa Barat yang merupakan daerah endemik defisiensi vitamin A. Lebih dari 50\% anak dari daerah ini mempunyai kadar vitamin A plasma $<0,7 \mathrm{Umol} /$ liter, dengan sebagian besar mempunyai status defisiensi vitamin A subklinis. Pada saat penelitian ini, di Jawa Barat anak di bawah usia 1 tahun tidak termasuk program pemberian vitamin $\mathrm{A}$ dosis tinggi baik berupa kapsul, tablet, injeksi atau lainnya.

\section{Bahan dan Cara}

Imunisasi campak dilakukan pada bayi usia 6 bulan karena ada bukti sebelumnya angka kejadian campak yang cukup tinggi pada usia tersebut. Pada bayi usia kurang lebih 6 bulan, setelah pengisian formulir persetujuan (informed consent) oleh orangtua bayi, dilakukan pengambilan darah untuk data titer antibodi campak dasar dan bayi diberikan imunisasi campak secara subkutan di lengan kanan atas dengan 0,5 ml vaksin campak Schwarz titer baku (Morbilivax, Lot 68A09, 10TCID 50/dosis, Biocine Sclavo, Siena,Itali). Secara random, bayi diberikan vitamin A 100.000 IU atau plasebo dalam bentuk kapsul yang identik (Task Force Sight and Life, Basel, Swis) pada saat imunisasi tersebut. Satu bulan kemudian, dilakukan pengambilan darah untuk menilai respons imun terhadap campak setelah vaksinasi. Pengambilan darah diulang setelah 6 bulan dari imunisasi. Titer antibodi terhadap campak dilakukan dengan cara plaque reduction neutralization oleh Division of Viral Product, US Food and Drug Administration, Bethesda, Maryland. Dianggap terjadi serokonversi bila terdapat kenaikan titer antibodi sesudah imunisasi sebesar $4 \mathrm{kali}$ atau lebih dibandingkan dengan sebelum imunisasi. Titer antibodi dianggap mempunyai nilai protektif bila $>1: 120$. Anak yang menderita malnutrisi atau sakit berat tidak diikutkan dalam penelitian.

Analisis statistik dilakukan dengan menggunakan analisis Chi-square dan exact test. Student's t-test digunakan untuk membandingkan nilai rerata geometrik dari kedua kelompok kontrol dan kelola.

\section{Hasil Penelitian}

Dari hasil penelitian didapatkan, sebanyak 336 anak diikutkan dalam penelitian. Jumlah yang datang pada tindak lanjut 1 bulan adalah 94\% dan setelah 6 bulan 90\%. Sampel dibagi 2 kelompok yaitu 169 anak kelompok vitamin A dan 167 anak kelompok plasebo. Di antara kedua kelompok tidak didapatkan perbedaan bermakna mengenai umur, usia ibu, jenis kelamin, berat badan terhadap tinggi, tinggi terhadap umur, lingkar lengan atas dan lingkar kepala. Hasil serokonversi terhadap campak setelah imunisasi adalah $78,5 \%$ pada kelompok vitamin A dan $84,7 \%$ pada kelompok plasebo $(\mathrm{p}=0,16)$. Hal yang sama terjadi setelah 6 bulan imunisasi, proporsi anak dengan titer protektif terhadap campak adalah $74,6 \%$ pada kelompok vitamin A dan 81,8\% pada kelompok plasebo $(p=0,13)$. Pada penelitian ini sebagian anak masih menunjukkan adanya antibodi maternal terhadap campak dengan berbagai titer. Untuk mengetahui pengaruh antibodi maternal pasif yang mungkin menghambat serokonversi setelah imunisasi, sampel dibagi 3 subkelompok berdasarkan titer antibodi maternal sebelum imunisasi yaitu subkelompok $\mathrm{A}$ anak dengan titer antibodi maternal $<1: 8$ yang dianggap seronegatif, subkelompok $B$ anak dengan titer antibodi maternal antara $>1: 8$ sampai $<1: 25$ dan subkelompok $\mathrm{C}$ anak dengan titer antibodi maternal $>1: 25$ yang mungkin menghambat respons imun terhadap vaksin campak. Lima anak dikeluarkan dari penelitian karena pernah menderita campak sebelumnya (titer sebelum imunisasi $>$ 1:500 dengan 
peningkatan $>4$ kali setelah 1 bulan imunisasi). Di antara subkelompok A didapatkan serokonversi setelah 1 bulan imunisasi sebesar $100 \%$ pada kelompok vitamin A dan 100\% pada kelompok plasebo dan titer protektif setelah 6 bulan adalah 97,9\% pada kelompok vitamin A dan 93,1 \% pada kelompok plasebo $(\mathrm{p}=0,25)$. Di antara subkelompok B didapatkan serokonversi setelah 1 bulan imunisasi sebesar 89,4\% pada kelompok vitamin A dan 96,1\% pada kelompok plasebo $(p=0,17)$ serta titer protektif setelah 6 bulan sebesar 74,4\% pada kelompok vitamin A dan 85,7\% pada kelompok plasebo $(p=0,17)$. Di antara subkelompok C didapatkan serokonversi setelah 1 bulan imunisasi sebesar $43,7 \%$ pada kelompok vitamin A dan $64,4 \%$ pada kelompok plasebo $(p=0,04)$ serta titer protektif setelah 6 bulan sebesar $50,0 \%$ pada kelompok vitamin A dan 69,6\% pada kelompok plasebo $(\mathrm{p}=0,03 \%)$. Titer rerata geometrik sebelum dan sesudah imunisasi terhadap campak terlihat pada Gambar 1, 2 dan 3.

Secara keseluruhan $12,4 \%$ anak dilaporkan timbul gejala ruam di seluruh tubuh dalam 2 minggu setelah imunisasi. Delapan persen anak yang mendapat vitamin A dan 15,9\% yang mendapat plasebo timbul gejala ruam $(\mathrm{p}<0,05)$. Pada subkelompok $\mathrm{A}, 7,4 \%$ anak yang mendapat vitamin $\mathrm{A}$ dan $4,3 \%$ anak yang mendapat plasebo timbul ruam $(\mathrm{p}=0,08)$. Pada subkelompok B, 15,2\% anak yang mendapat vitamin A dan 21,6\% anak yang mendapat plasebo timbul ruam $(\mathrm{p}<0,03)$. Pada subkelompok $\mathrm{C}$, timbul ruam pada $1 \%$ anak yang mendapat vitamin $\mathrm{A}$ dan $20,3 \%$ pada anak yang mendapat plasebo $(\mathrm{p}<0,01)$ seperti tampak pada Tabel 1 .

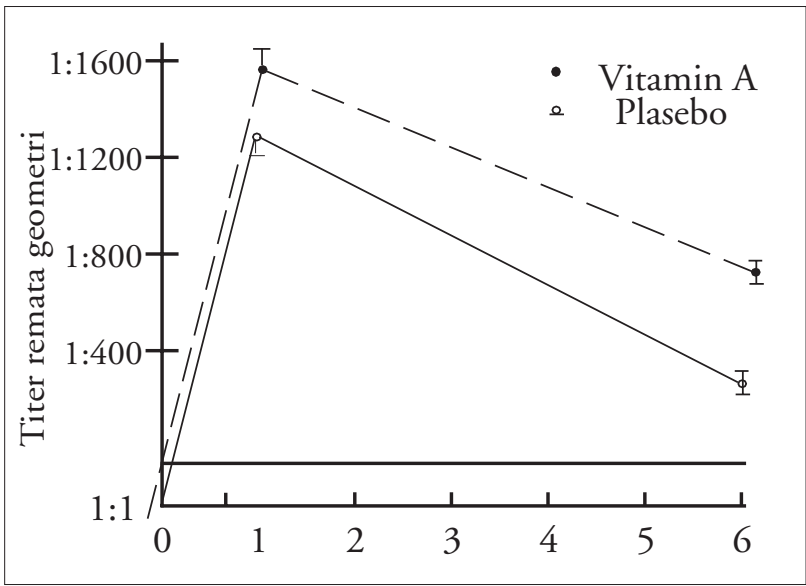

Gambar 1. Titer Remata Geometrik Sub-kelompok A
Dari hasil penelitian di atas dilaporkan tidak didapatkan adanya efek samping pemberian vitamin A dosis tinggi yang berarti.

\section{Diskusi}

Pemberian suplementasi vitamin A pada penelitian ini bertujuan meningkatkan proporsi serokonversi terhadap imunisasi campak yang mungkin kurang baik pada anak dengan defisiensi vitamin A. Dari hasil penelitian ini ternyata didapatkan hasil yang berbeda dari yang diharapkan. Pada penelitian ini tampak bahwa pada subkelompok $\mathrm{C}$ dengan titer antibodi maternal tertinggi didapatkan angka serokonversi hanya sebesar $43,7 \%$ pada kelompok vitamin A dan $64,4 \%$ pada kelompok plasebo $(\mathrm{p}<0,04)$; sedangkan

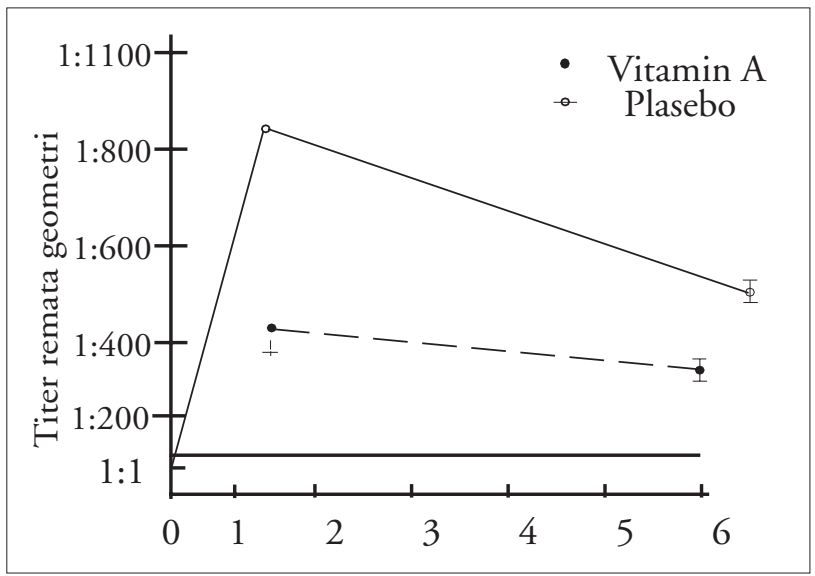

Gambar 2. Titer Remata Geometrik Sub-kelompok B

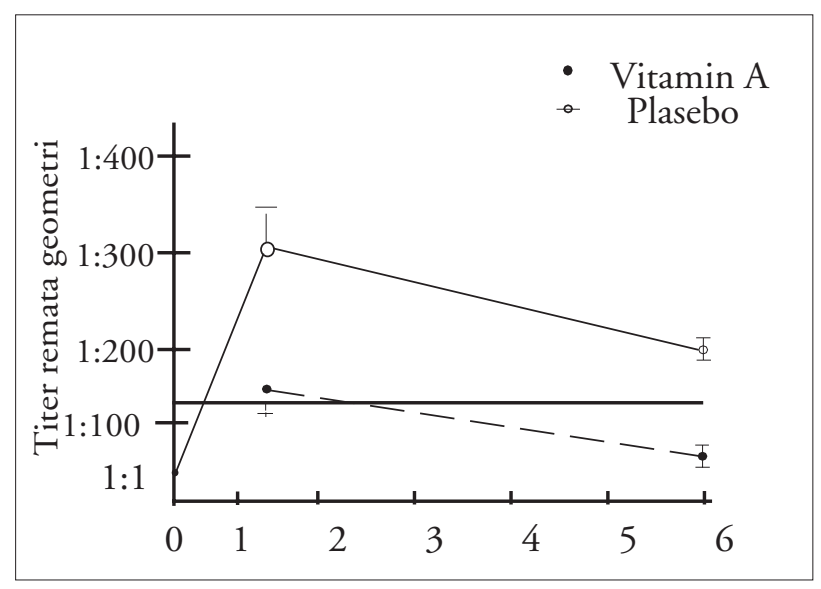

Gambar 3. Titer Remata Geometrik Sub-kelompok C 
Sari Pediatri, Vol. 2, No. 2, Agustus 2000

Tabel 1. Pengaruh suplementasi vitamin A pada serokonversi, vaksinasi campak dan timbulnya gejala ruam.

\begin{tabular}{lcccccc}
\hline Evaluasi & \multicolumn{2}{c}{ Subkelompok A(\%) } & \multicolumn{2}{c}{ Subkelompok B(\%) } & \multicolumn{2}{c}{ Subkelompok C(\%) } \\
& $\begin{array}{c}\text { Vit.A } \\
(\mathrm{n}=54)\end{array}$ & $\begin{array}{c}\text { Plasebo } \\
(\mathrm{n}=46)\end{array}$ & $\begin{array}{c}\text { Vit.A } \\
(\mathrm{n}=47)\end{array}$ & $\begin{array}{c}\text { Plasebo } \\
(\mathrm{n}=52)\end{array}$ & $\begin{array}{c}\text { Vit.A } \\
(\mathrm{n}=48)\end{array}$ & $\begin{array}{c}\text { Plasebo } \\
(\mathrm{n}=56)\end{array}$ \\
\hline Serokonversi + & 100 & 100 & 89, & 96,1 & $43,7^{*}$ & 64,4 \\
Titer proteksi++ & 97,9 & 93,1 & 74,4 & 85,7 & 50,0 & 69,6 \\
Gejala ruam & 7,4 & 4,3 & $15,2^{*}$ & 21,6 & $1^{*}$ & 20,3 \\
\hline
\end{tabular}

$+\quad$ Peningkatan 4 kali lebih titer antibodi pada 1 bulan setelah imunisasi

$+\quad$ Titer antibodi $>1: 120 \quad 6$ bulan setelah imunisasi

* Perbedaan kedua kelompok $\mathrm{p}<0,05$

proporsi anak dengan titer protektif setelah 6 bulan imunisasi lebih rendah secara bermakna pada kelompok vitamin A Tabel 1. Efek ini ternyata tidak hanya disebabkan oleh antibodi maternal saja karena sebelum imunisasi titer rerata geometrik tidak berbeda bermakna di antara kelompok vitamin A. Titer rerata geometrik sebelum dan sesudah imunisasi terhadap campak pada anak subkelompok A,B dan $C$ terlihat pada gambar 1,2 dan 3. Di antara subkelompok A yang mendapat vitamin A mempunyai titer antibodi yang lebih tinggi setelah 6 bulan imunisasi $(\mathrm{p}<0,03)$. Pada subkelompok $\mathrm{B}$, anak yang mendapat vitamin $\mathrm{A}$ mempunyai titer yang lebih rendah setelah imunisasi $(\mathrm{p}=0,07)$ dan 6 bulan setelah imunisasi $(\mathrm{p}<0,05)$ dibandingkan dengan anak yang mendapat plasebo. Pada subkelompok $\mathrm{C}$, anak yang mendapat vitamin A mempunyai titer yang lebih rendah setelah 1 bulan imunisasi $(\mathrm{p}=0,07)$ dan 6 bulan setelah imunisasi $(\mathrm{p}<0,05)$ dibandingkan dengan kelompok plasebo. Secara keseluruhan $12,4 \%$ anak yang dilaporkan timbul gejala ruam di seluruh tubuh dalam 2 minggu setelah vaksinasi campak. Pada subkelompok B dan C dengan titer antibodi maternal yang masih tinggi anak yang mendapat vitamin A lebih sedikit timbul ruam dibandingkan dengan anak yang mendapat plasebo dengan perbedaan yang sangat bermakna. Selama masa akut komplikasi penyakit campak, telah dibuktikan bahwa pemberian suplemen vitamin A dapat mengurangi morbiditas dan mortalitas, peningkatan respons antibodi dan membatasi infeksi. ${ }^{2}$ Imunisasi dengan vaksin virus campak hidup biasanya diikuti oleh gejala infeksi subklinis oleh virus campak yang dilemahkan dan timbul serokonversi terhadap campak.
Kombinasi antara antibodi maternal dan peningkatan respons imun oleh vitamin A mungkin menghambat kesanggupan virus vaksin untuk menimbulkan infeksi subklinis, sehingga vaksin kurang efektif dan menyebabkan kegagalan vaksin primer. Dari hasil penelitian ini dan juga penelitian sebelumnya tampak bahwa vitamin A dapat menghambat infeksi baik virus tipe ganas atau virus vaksin yang dilemahkan. Pada anak yang mendapat vitamin A lebih sedikit timbul gejala ruam stelah imunisasi. Hal ini menunjukkan bahwa vitamin A dapat menghambat replikasi virus vaksin.

Dari hasil penelitian di atas terbukti vitamin A dapat menghambat replikasi virus vaksin campak dengan peningkatan respons imun. Ternyata suplementasi vitamin A dosis tinggi juga bermanfaat pada pasien campak.

Penyakit campak masih merupakan masalah di Indonesia. Sampai sekarang belum ada pengobatan yang spesifik untuk penyakit tersebut. Penyakit ini dapat berakhir fatal bila bila terjadi komplikasi berat seperti ensefalitis dan pneumonia terutama pada pasien malnutrisi dengan kekebalan tubuh yang rendah. Umumnya pada pasien malnutrisi selain menderita kekurangan protein dan karbohidrat juga didapatkan defisiensi berbagai mikronutrien diantaranya adalah defisiensi vitamin A. Defisiensi vitamin A seperti juga status gizi , status vitamin A dibagi dalam 5 tingkatan yaitu defisiensi, marginal, memuaskan, berlebih dan toksik. ${ }^{10}$ Status vitamin A defisiensi ditandai dengan gejala klinis yang jelas yaitu gejala seroftalmi dan pada status hipervitaminosis / toksik ditandai dengan sakit kepala, penglihatan ganda serta rambut rontok. Pada 
status marginal tidak menunjukkan gejala klinis akan tetapi terdapat cadangan vitamin A yang kurang. Pada status vitamin A berlebih, juga tidak menunjukkan gejala klinis tetapi terdapat cadangan vitamin A yang berlebihan dengan risiko manifestasi toksik pada masukan vitamin A yang tinggi atau adanya infeksi virus tertentu misalnya virus hepatitis yang menyerang sel hati yang merupakan tempat cadangan vitamin A. Status marginal mempunyai risiko kematian lebih tinggi di negara tertentu karena tidak menunjukkan gejala klinis sehingga luput dari pemberian suplementasi vitamin A. ${ }^{11}$ Status marginal ini mudah jatuh ke status defisiensi pada keadaan stress atau infeksi termasuk infeksi campak. Pemberian suplemen vitamin A dosis tinggi dilaporkan dapat mengurangi angka kematian lebih dari 50\% pasien campak sedang maupun berat. ${ }^{2}$ Dari hasil penelitian secara buta ganda, kontrol-plasebo mengenai efek suplementasi vitamin A dosis tinggi terhadap respons imun pada vaksinasi campak usia 6 bulan di daerah Bogor, didapatkan gangguan serokonversi dan peningkatan fungsi sel NK (natural killer). Hal ini mungkin disebabkan efek vitamin A terhadap peningkatan fungsi sel NK yang berperan dalam eliminasi virus pada vaksin sehingga dosis virus pada vaksin menurun yang menyebabkan rendahnya pembentukan antibodi terhadap virus campak .

Manfaat pemberian suplementasi vitamin A telah dibuktikan pada uji klinis secara acak pada 189 anak yang dirawat di rumah sakit di Afrika Selatan yang menderita campak dengan komplikasi pneumonia, diare atau infeksi saluran napas atas. ${ }^{2}$ Subyek dengan usia median 10 bulan dibagi 2 kelompok yaitu kelompok yang menerima vitamin A dengan dosis total 400 IU retinol palmitat serta kelompok yang menerima plasebo yang diberikan dalam 5 hari dari awitan ruam. Vitamin A ini diberikan secara peroral atau intragastrik, yaitu setengah dosis diberikan pada saat masuk rumahsakit dan sisanya pada hari berikutnya. Dibandingkan dengan kelompok plasebo, perbaikan terhadap pneumonia, diare dan infeksi saluran napas atas secara bermakna lebih cepat terjadi pada kelompok vitamin A dengan masa perawatan yang lebih pendek. Dari 12 pasien yang meninggal, 10 di antaranya terjadi pada kelompok kontrol. Risiko kematian karena komplikasi selama perawatan di rumahsakit hanya separuh dari risiko kematian pada kelompok kontrol. Dari penelitian tersebut disimpulkan bahwa pe- ngobatan dengan suplementasi vitamin A dosis tinggi dapat mengurangi angka morbiditas dan mortalitas dan dianjurkan untuk memberikan suplementasi vitamin A pada semua pasien campak baik pada anak dengan gizi baik maupun malnutrisi.

Dengan adanya fakta yang telah dikemukakan di atas yaitu vitamin A dapat menghambat replikasi virus vaksin campak maka pada pasien campak sangat dianjurkan untuk memberikan suplementasi vitamin A dosis tinggi yaitu sampai 400.000 IU pada saat terjadi ruam dalam 2 hari berturut-turut dan pada anak di bawah usia 1 tahun dapat diberikan dosis sampai 100.000 IU tanpa efek samping yang berarti seperti yang telah dilaporkan pada hasil penelitian di atas. Selain pemberian suplementasi vitamin A terapi penunjang lain yang memadai tetap diberikan.

\section{Daftar Pustaka}

1. Assaad F. Measles: Summary of world wide impact. Rev Inf Dis 1983; 5:452-9.

2. Hussey GD, Klein M. A randomized, controlled trial of vitamine A with severe measles. N Eng J Med 1990; 323:160-4.

3. Sommer A, Tarwotjo I, Husaini G, Susanto D. Increased mortality in children with mild vitamine A deficiency. Lancet 1983 ; 2:585-8.

4. Smith SM, Levy NS, Hayes CE. Impaired immunity in vitamine A deficient mice. J Nutr 1986; 117:857-65.

5. Nauss KM, Mark DA, Suskind RM. The effect of vitamine A deficiency on the invitro cellular immune response of rats. J Nutr 1979;109:1815-23.

6. Bendich A. Antioxidant micronutrients and immune response. Dalam: Bendich A, Chandra RK, Penyunting. Micronutrients and immune function. New York: New York Academy of Sciences, 1990; 323:160-80.

7. Mey Dani SW, Barklund MP, Liu S dkk. Penyunting. Vitamine E supplementation enhances cell mediated immunity in healthy elderly subjects. Am J Clin Nutr 1990; 52:557-63.

8. Dresser DW. Adjuvanticity of vitamine A. Nature 1968; 217:527-9.

9. Freud J. Nature and significance of the antibody response. Columbia Univ Press, 1953.

10. Olson JA. Vitamine A. Dalam: Machlin LJ, penyunting. Modern nutrition in health and disease; ed.7.Philadelphia: Lea \& Febiger, 1988:h.292-312.

11. Sommer A. New imperative in an old vitamine A. J Nutr 1989; 119:96-100.

12. Munasir Z, Gunardi H, Satari HI, Jer MM. Measles antibody titer in elementary school children in Jakarta. Diajukan pada Asian Congress of Pediatrics, Taiwan 1999. 